TATSIANA VALODZINA

Narodowa Akademia Nauk Białorusi

tanja_volodina@tut.by

ORCID: 0000-0002-9800-2199

TATSIANA MARMYSH

Narodowa Akademia Nauk Białorusi

ta-m@tut.by

ORCID: 0000-0003-0896-8553

\title{
Tradycje bajkowe w świecie współczesnym. Uwagi na marginesie II Forum Badaczy Białoruskiej Bajki
}

\section{Fairytale traditions in the modern world: On the margins of the II Forum for Researchers of Belarusian Fairy Tales}

II Forum Badaczy Białoruskiej Bajki (Mińsk, 27-29 maja 2021 r.) / II Forum for Researchers of Belarusian Fairy Tales (Minsk, May 27-29, 2021).

DOI: $10.12775 /$ LL.3.2021.0011 | CC BY-ND 4.o

Proza bajkowa jest jednym z najważniejszych elementów białoruskiej kultury ludowej, który do dziś zachowuje swoje walory estetyczne, poznawcze i edukacyjne, a tym samym warto go analizować w szerszym kontekście regionalnym i międzynarodowym. Jedną z okazji do takiej analizy jest Forum Badaczy Białoruskiej Bajki, które już po raz drugi zostało zorganizowane przez Centrum 
Badań nad Białoruską Kulturą, Językiem i Literaturą Narodowej Akademii Nauk Białorusi (CBBKJL). Druga edycja tego wydarzenia odbyła się w dniach 27-29 maja 2021 r. i stanowiła kontynuację spotkania o tej samej nazwie z 2018 r. Jej uczestnicy podjęli rozważania dotyczące całokształtu motywów i obrazów obecnych w białoruskiej bajce, a zarazem zademonstrowali istotne osiagnięcia w badaniach bajkoznawczych i popularyzacji bajek z różnych krajów europejskich.

Program Forum podzielony był na dwie ścieżki - naukową i edukacyjną. W ramach tej pierwszej odbyło się główne wydarzenie, czyli międzynarodowa konferencja zatytułowana Bajka ludowa w przestrzeni europejskiej. Tradycja archaiczna vs interpretacja nowoczesna, w której uczestniczyli naukowcy z Białorusi, Rosji, Polski, Estonii, Ukrainy, Francji, Bułgarii i Litwy. Ze względu na sytuacje związaną z pandemią koronawirusa całe wydarzenie miało formę hybrydową; większość uczestników zagranicznych brała w nim udział zdalnie, natomiast badacze białoruscy wygłaszali swoje referaty stacjonarnie.

Konferencję rozpoczęła sesja plenarna, podczas której zaprezentowano m.in. następujące zagadnienia: Galina Kabakova (Uniwersytet Paryski, Paryż) omówiła problematykę związaną z publikowaniem, tłumaczeniem i katalogowaniem bajek etiologicznych. Violetta Wróblewska (Uniwersytet Mikołaja Kopernika, Toruń) zaprezentowała projekt Stownik polskiej bajki ludowej. Katarzyna Smyk (Uniwersytet Marii Curie-Skłodowskiej, Lublin) przedstawiła referat, w którym wykorzystała teorię Włodzimierza Proppa do semiotycznej analizy obrzędów na przykładzie tradycji układania dywanów kwiatowych na procesję Bożego Ciała w Spycimierzu. Tatsiana Valodzina (Wydział Folklorystyki i Kultury Narodów Słowiańskich, Narodowa Akademia Nauk Białorusi, Mińsk), omówiła historię badań nad białoruską bajką ludową oraz nowoczesne projekty związane z jej badaniami. Varvara Dobrovolskaya (Wydział Niematerialnego Dziedzictwa Kulturowego, Rosyjski Państwowy Dom Twórczości Ludowej, Moskwa) przedstawiła osiągnięcia i problemy związane z badaniami nad bajkami w Rosji. Zurab Dzhapua (Akademia Nauk Abchazji, Suchumi) skupił się na analizie twórczości abchaskiej narratorki bajek ludowych Luby Dzhapua. Yekaterina Anastasova (Dział Etnologii Bałkańskiej, Bułgarska Akademia Nauk, Sofia) zaprezentowała referat na temat obecności bajek we współczesnym dyskursie politycznym. Z kolei w referacie Anzheliki Jakubyniene (Instytut Literatury i Folkloru Litewskiego, Wilno) został podniesiony temat cyfrowych bajek litewskich w kształtowaniu światopoglądu dzieci'.

Podczas sesji plenarnej omówiono również wiele innych zagadnień, jednak już wskazane powyżej przykłady pokazują różnorodność podejmowanej problematyki oraz dążenie naukowców do podkreślania $\mathrm{z}$ jednej strony narodowych odrębności bajkowych tradycji, z drugiej strony uniwersalności bajki ludowej.

1 Nagrania wystąpień uczestników posiedzenia plenarnego umieszczone są na kanale Wydziału Folklorystyki i Kultury Narodów Słowiańskich Narodowej Akademii Nauk Białorusi pod linkiem https://www.youtube.com/channel/UC 3 VAr1xs9TfYV51kxe96NBA. 
W dalszej części konferencji dwudniowe obrady prowadzone były w pięciu sekcjach: „Historia zbierania i badań bajek ludowych. Osobowość bajarza i typy bajarzy”, „Wzajemne wpływy i paralele w bajkowym folklorze. Poetyka i semantyka bajki ludowej”, „Interpretacja bajki ludowej w sztuce”, „Bajka i bajkowość w historii literatury”, „Rozwój i transformacja bajki w literaturze współczesnej”. W sumie wygłoszono 68 referatów, w których poruszono wiele kwestii istotnych dla białoruskiej folklorystyki. Mówiono m.in. o zagadnieniach przestrzeni i czasu w kompleksowym badaniu bajki, o relacjach pomiędzy tradycją bajkową a kulturą piśmienną i intermedialnością; zastanawiano się także nad powiązaniem bajki z innymi gatunkami folkloru, nad poetyką i obrazowaniem w bajce ludowej i literackiej, znaczeniem słowa $\mathrm{w}$ opowiadaniu bajek oraz problemami klasyfikacji wątków bajowych. Nie umknął uwadze również problem sztuki opowiadania (storytelling) jako zjawiska kultury współczesnej oraz wykorzystania bajek w dyskursie społeczno-politycznym do budowania tożsamości narodowej.

Prócz konferencji naukowej w ramach Forum zorganizowano również wydarzenia o charakterze edukacyjno-poznawczym. Pierwszego dnia odbyła się m.in. wystawa Pskowskie bajki dla dzieci autorstwa Yekateriny Yefimovej z Pskowa (Rosja). Uczestnicy mieli okazję zapoznać się z ilustracjami do białoruskich bajek autorstwa nauczycieli i studentów Białoruskiej Państwowej Akademi Sztuk Pięknych oraz książkami z zasobów Centralnej Biblioteki Naukowej im. Yakuba Kolasa Narodowej Akademii Nauk Białorusi.

W drugim dniu Forum odbył się otwarty panel dyskusyjny pt. Wspótczesna bajka literacka. Między fikcja a prawda pod przewodnictwem pisarza Syarhyeya Minskevicha. W trakcie panelu dyskutowano na temat rozmaitych zagadnień bajkoznawczych, od problemów związanych z badaniami bajki autorskiej, do kwestii ekonomicznego wsparcia wydawców bajek i promocji ich publikacji. Omawiana była również obecność bajek w szkolnych programach edukacyjnych, zakres wykorzystywania bohaterów folkloru bajkowego w produkcji reklamowej, turystyce, grach komputerowych i literaturze współczesnej, a także kierunki rozwoju bajki autorskiej. Uczestnicy panelu stwierdzili, że istnieje pilna potrzeba opublikowania antologii współczesnej bajki białoruskiej.

Kolejnym wydarzeniem podczas Forum była prezentacja archiwalnych zbiorów bajek z trzech największych kolekcji folklorystycznych w kraju: Archiwum Folklorystycznego Centrum Badań nad Białoruską Kulturą, Językiem i Literaturą (Narodowa Akademia Nauk Białorusi), Edukacyjno-Naukowego Laboratorium Folkloru Białoruskiego Uniwersytetu Państwowego oraz Archiwum Folklorystycznego Połockiego Uniwersytetu Państwowego.

Dużym zainteresowaniem cieszył się także warsztat Natallii Sukhai, mistrzyni ludowej, arteterapeutki, członkini Białoruskiego Związku Mistrzów Sztuki Ludowej i Studenckiego Stowarzyszenia Etnograficznego. Artystka wprowadziła wszystkich w świat bajki za pomocą tradycyjnej techniki wycinania z papieru. Uczestnicy Forum - a także zagraniczni studenci mińskich uczelni - mieli okazje spróbować swoich sił w sztuce wycinanki, za pomocą której każdy starał się stworzyć swoją osobistą bajkę. 
W trakcie Forum odbyły się również prezentacje wielu publikacji poświęconych bajkom, m.in. książki pt. I ya tam byw.....” (z narodnapaetychnay spadchyny) (Lakotka 2020), zawierającej tłumaczenia białoruskich bajek ludowych na język angielski i chiński, oraz płyty Vitsyebska-Velizhskiya zapisy (Vnukovich, Hrynyevich 2021). Ta ostatnia publikacja zawiera zdigitalizowane materiały zebrane przez białoruskich folklorystów Kanstantsina Kabashnikava i Halinę Bartashevich podczas badań na białorusko-rosyjskim pograniczu prowadzonych w 1989 r., a prezentowane nagrania obejmują pieśni obrzędowe oraz wywiady etnograficzne ze zbiorów Archiwum Folklorystycznego CBBKJL. Z kolei badacze z Rosyjskiego Domu Twórczości Ludowej (Moskwa) zapoznali publiczność z seriami książkowymi Folklornyy arkhiv: Permskiy kray (Chernykh 2020a; Chernykh 202ob) i Skazki narodov Yevrazii (Khabunova 2017; Khabunova 2018; Khabunova 2020).

Warto podkreślić, że w Forum uczestniczyli nie tylko naukowcy, lecz także depozytariusze tradycji. Wystąpienia mistrzów-gawędziarzy średniego i starszego pokolenia $\mathrm{z}$ różnych regionów Białorusi wyróżniały się bogactwem wątków i emocjonalnością wypowiedzi. Swoje umiejętności opowiadania zademonstrowali Lyudmila Hlukhatarenka (Sanyuki, rejon jelski), Safiya Katok i Raisa Kahadowskaya z zespołu ludowego „Byerazhnitsa” (Plastok, obwód lubański), Alyaksandr Halkowski (Sudzily, rejon klimowicki), Liliya Rezkina (Witebsk), Larysa Ryzhkova, kierownik zespołu ludowego „Kalychanka” (Michanowicze, rejon miński); z kolei rosyjskie bajki ludowe przedstawiła Yevgeniya Krivenko z Pskowa.

Organizatorzy Forum postawili również pytanie: Jak zainteresować bajką dzieci? Odpowiedź miał przynieść konkurs młodych wykonawców białoruskiej bajki. Jego celem było zwiększenie zainteresowania młodych Białorusinów białoruskim językiem i kulturą poprzez skierowanie ich uwagi na bajkę ludową. Młodzi bajarze mieli za zadanie nagrać krótki film, na którym opowiadają swoją ulubioną bajkę, następnie z pomocą rodziców, nauczycieli lub starszych przyjaciół umieścić go na swojej stronie w mediach społecznościowych, oznaczając hashtagami \#конкурсказкі 2021, \#казка 2021, \#belarusiantails2021. CBBKJL po raz pierwszy zdecydował się na taki nowoczesny i nietypowy format konkursu, który znakomicie się sprawdził i pozwolił w pełni zrealizować cel projektu. Filmy umieszczone na profilach wykonawców miały wiele odsłon i polubień, a organizatorzy otrzymali w sumie do oceny 52 bajki z całej Białorusi; najmłodszy wykonawca miał zaledwie pięć lat, najstarszy zaś 15. Podczas ceremonii ogłoszenia wyników konkursu widzowie zobaczyli najlepsze filmy, a zwycięzcy i uczestnicy otrzymali nagrody. Pierwsze miejsce zajęli Dabrana Mishurnaya (Wymna, rejon witebski), która opowiedziała bajkę Kaza-manyuka (Koza-kłamca) oraz Kiryl Kudzin (Miotcza, rejon borysowski), który opowiedział bajkę Pra barana (O baranie). Drugie miejsce zdobyła bajka Chamu kot myauchy (Dlaczego kot miauczy) w wykonaniu Aryny Shafarovich (Woropajewo, rejon postawski) oraz bajka Hleba Sidarava (Wymna, rejon witebski) Bylinka $i$ wyerabyey (Źdźbło trawy i wróbel). Trzecie miejsce jury przyznało bajkom Mirona Klyeshchyka z Mińska Ishow mal’chyk (Chłopiec szedł) i Kiry Avtukhovej (Nowosiele, rejon miński) Pchala i mukha (Pszczoła i mucha). 
Zarówno refleksje prezentowane podczas konferencji naukowej, jak i inne wydarzenia odbywające się w ramach Forum pozwalają stwierdzić, że liczba depozytariuszy tradycji bajkowej ciągle się zmniejsza, dlatego w jej zachowaniu wzrasta rola fachowców - badaczy, członków zespołów folklorystycznych, muzealników. Bajka ludowa nadal istnieje w życiu współczesnego człowieka głównie dzięki badaniom i projektom naukowym oraz twórczości artystycznej dzieci i dorosłych. II Forum Badaczy Białoruskiej Bajki spełniło więc ważną role w zakresie podtrzymywania i upowszechniania tradycji bajowych, a jego organizatorzy planują kolejną edycję spotkania, która odbędzie się za dwa lata.

\section{BIBLIOGRAFIA}

Chernykh, A. V. (ed.) (2020a). Russkiye skazki Permskogo kraya v zapisyakh kontsa XX - nachala XXI v. Sankt-Peterburg: Izdatel'stvo „Mamatov”.

Chernykh, A. V. (ed.) (202ob). Skazki Yevdokii Nikitichny Tryastsinoy. Sankt-Peterburg: Izdatel'stvo "Mamatov".

Khabunova Ye. E. (ed.) (2017). Skazki narodov Yevrazii: Syn medvedya. Elista: Izdatel'stvo Kalmytskogo Universiteta.

Khabunova, Ye. E. (ed.) (2018). Skazki narodov Yevrazii: Machekha i padcheritsa. Elista: NPP „Dzhangar”.

Khabunova, Ye. E. (ed.) (2020). Skazki narodov Yevrazii: Khitraya nauka. Elista: Izdatel'stvo Kalmytskogo Universiteta.

Lakotka, A. I. (ed.) (2020). „I ya tam byw...” (z narodnapaetychnay spadchyny). Minsk: Byelaruskaya Navuka.

Vnukovich, Yu. I., Hrynyevich, Ya. I. (eds.) (2021). Vitsyebska-vielizhskiya zapisy: Z elyektronnym dadatkam. Minsk: Byelaruskaya Navuka. 